\title{
Mechanisms of Superoxide Signaling in Epigenetic Processes: Relation to Aging and Cancer
}

\author{
Igor Afanas'ev \\ Vitamin Research Institute, Moscow, Russia, Porto, Portugal \\ [Received August 7, 2014; Revised September 20, 2014; Accepted September 24, 2014]
}

\begin{abstract}
Superoxide is a precursor of many free radicals and reactive oxygen species (ROS) in biological systems. It has been shown that superoxide regulates major epigenetic processes of DNA methylation, histone methylation, and histone acetylation. We suggested that superoxide, being a radical anion and a strong nucleophile, could participate in DNA methylation and histone methylation and acetylation through mechanism of nucleophilic substitution and free radical abstraction. In nucleophilic reactions superoxide is able to neutralize positive charges of methyl donors S-adenosyl-L-methionine (SAM) and acetyl-coenzyme A (AcCoA) enhancing their nucleophilic capacity or to deprotonate cytosine. In the reversed free radical reactions of demethylation and deacetylation superoxide is formed catalytically by the (Tet) family of dioxygenates and converted into the iron form of hydroxyl radical with subsequent oxidation and final eradication of methyl substituents. Double role of superoxide in these epigenetic processes might be of importance for understanding of ROS effects under physiological and pathological conditions including cancer and aging.
\end{abstract}

Key words: superoxide, DNA and histone methylation and acetylation, aging, cancer

Superoxide, an anion radical of dioxygen, is the precursor of paramagnetic reactive free radicals (hydroxyl radicals) and reactive diamagnetic molecules (hydrogen peroxide and peroxynitrite) in biological systems. At the same time, although superoxide by itself is not a reactive free radical, it is a very reactive nucleophilic agent (a super-nucleophile) [1, 2]. History of superoxide discovery is a really dramatic and fascinated one. In 1968, McCord and Fridovich proposed that superoxide existed in biological systems as a free diffusing species [3]. This stimulating hypothesis has been accepting by many authors who started to study enthusiastically the mechanisms of possible damaging effects of superoxide.

Much earlier Haber and Weiss proposed that the hydroperoxyl radical $\left(\mathrm{HOO}^{\circ}\right)$ can participate in the decomposition of hydrogen peroxide to form the reactive hydroxyl radicals [4]. Therefore, the participation of superoxide in a so called Haber-Weiss cycle has been proposed:

$$
\begin{aligned}
& \mathrm{O}_{2}^{\bullet^{-}}+\mathrm{H}_{2} \mathrm{O}_{2} \rightarrow \mathrm{O}_{2}+\mathrm{HO}^{\bullet}+\mathrm{HO}^{-} \\
& \mathrm{HO}^{-}+\mathrm{H}_{2} \mathrm{O}_{2} \rightarrow \mathrm{H}_{2} \mathrm{O}+\mathrm{O}_{2}^{0^{-}}+\mathrm{H}^{+}
\end{aligned}
$$

However, it was soon established that these reactions are thermodynamically impossible; therefore, it was suggested that the Haber-Weiss cycle might be catalyzed by iron ions. Correspondingly, this process was named "the superoxide-dependent Fenton reaction" (by the name of a French chemist discovered "Fenton reagent" [5]):

$$
\begin{aligned}
& \mathrm{O}_{2}^{\bullet^{-}}+\mathrm{Fe}(\mathrm{III}) \rightarrow \mathrm{O}_{2}+\mathrm{Fe}(\mathrm{II}) \\
& \mathrm{Fe}(\mathrm{II})+\mathrm{H}_{2} \mathrm{O}_{2} \rightarrow \mathrm{Fe}(\mathrm{III})+\mathrm{HO}^{\bullet}+\mathrm{HO}^{-}
\end{aligned}
$$

*Correspondence should be addressed to: Dr. Igor Afanas'ev. Vitamin Research Institute, Moscow, Russia, Porto, 
In vitro experiments confirmed a high efficiency of the superoxide-dependent Fenton reaction, but later on it was found that the in vitro experiments were erroneous because an effective artificial chelator EDTA was presented in reaction mixtures, which of course was absent in real biological systems. Thus, the in vivo transformation of superoxide into hydroxyl radicals seems to be very questionable.

On the other hand, it has been found that superoxide is able to participate in the other important biological reactions, namely in the reactions of nucleophilic substitution. Numerous chemical studies demonstrated the ability of superoxide to take part in the nucleophilic reactions of hydrolysis and esterification [1]. Correspondingly, in 1978 Niehaus proposed that superoxide might be involved in enzymatic nucleophilic reactions such as phosphorylation, acetylation, etc. [6]. I am certain that this proposal was a really important and promising idea (see, for example [7]).

\section{Mechanisms of superoxide signaling in epigenetic processes}

\section{Nucleophilic Substitution Reactions of DNA Methylation, Histone Methylation, and Histone Acetylation}

It is possible that superoxide plays an important role in such epigenetic processes as DNA methylation (catalyzed by methyltransferases (DNMT)), histone methylation (catalyzed by lysine methyltransferases (PKMT)), and histone acetylation (catalyzed by histone acetyltransferases (HAT) in both physiological and pathological states including cancer and aging. It has been proposed that DNA and histone modifications are carried out by two major mechanisms: the reactions of nucleophilic addition of methyl and acetyl groups and the reactions of demethylation by free radical abstraction. These reversible, or more correctly, pseudo-reversible epigenetic processes of DNA and histone modification are probably the unique examples of chemical processes in which the forward and reversed reactions proceed by completely different mechanisms. Reactions of DNA methylation and histone acetylation go on by similar mechanisms with participation of the intermediates S-adenosyl-L-methionine (SAM) and Accoenzyme A (AcCoA) [8-12]. It is usually believed that these reactions are nucleophilic substitution processes, although they do not exactly correspond to the original name given by ED Hughes and C Ingold (1935). By their definition, a nucleophilic reaction is the addition of the substituent to a carbon atom by the negatively charged reactant (nucleophile). However, the substitution of a hydrogen atom by the methyl group at the cytosine C5 position during DNA methylation does not correspond to the original definition of nucleophilic process because the methyl group is transferred from the positively (and not negatively) charged $\left(-\mathrm{S}^{(+)}\right)$center of SAM (Figure $1 \mathrm{~A})$.
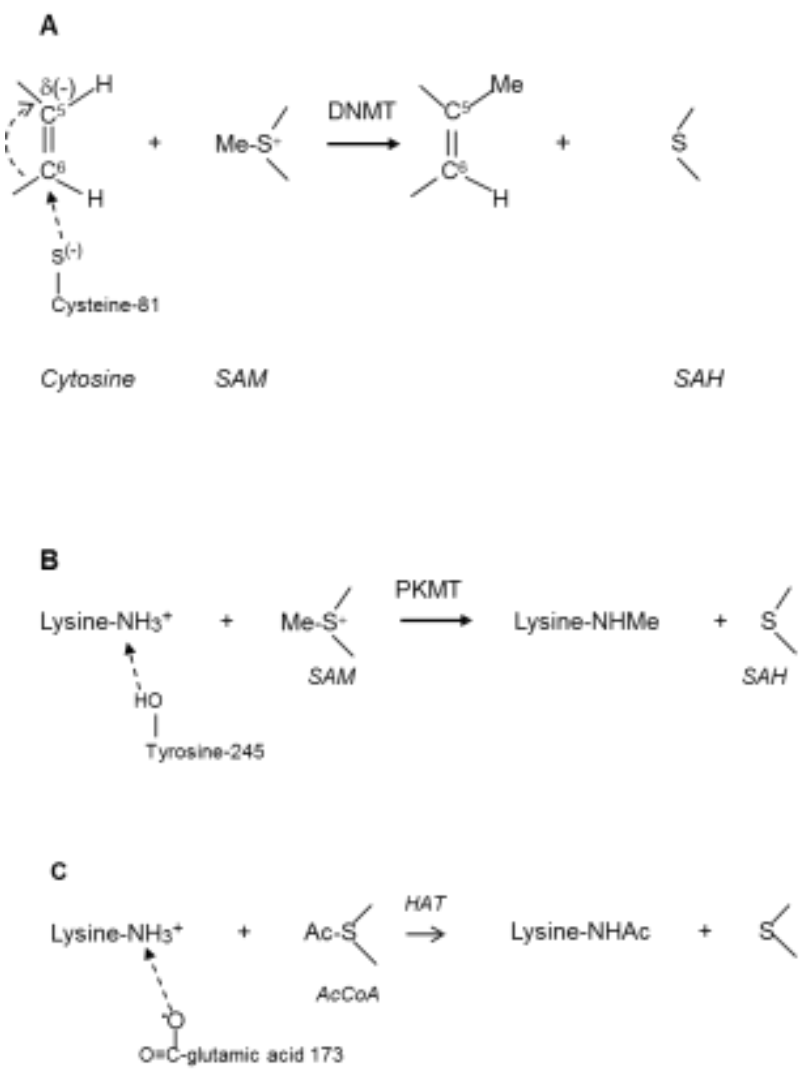

Figure 1. Mechanism of DNMT- catalyzed DNA methylation. A. SAM-dependent methylation of cytosine catalyzed by methyltransferases (DNMT). B. SAM-dependent methylation of lysine catalyzed by lysine methyltransferases (PKMT). C. AcCoA-dependent acetylation of lysine catalyzed by histone acetyltransferases (HAT).

Similarly, the histone amino group $\left(-\mathrm{NH}_{3}+\right)$ is also positively charged during the methylation and acetylation of histones (Figure 1B and 1C).

It was proposed that in order to validate a nucleophilic mechanism of these reactions we needed to assume that the positive charges of reactants were neutralized by nearby nucleophiles. Thus, the interaction of cytosine C- 6 carbon with the negatively charged cysteine- 81 residue transforms the $\mathrm{C}-5$ position into a partly negative one and makes possible nucleophilic substitution by the SAM methyl group. It was also 
suggested that the C-6 atom of cytosine might be connected to cysteine- 81 by a covalent or hydrogen bonds. Similarly, histone nucleophilic methylation becomes possible if $\left(\mathrm{NH}_{3}+\right.$ ) group is attached (presumably by a hydrogen bond) to tyrosine-245 residue.

Histone acetylation is catalyzed by several HAT enzymes through the formation of a complex of histone, acetyl-CoA, and HAT. In this reaction, the amino group of lysine residue directly attacks the bound acetyl-CoA. However, nucleophilic reaction again becomes possible only after the deprotonation of amino group when glutamic acid-173 participates in acetylation as a general base (Figures 1A-C).

These nucleophilic mechanisms are very elegant and supported by some experimental data, but there are questions, which are needed to be clarified. For example, a nature of the bond between a base and the histone protonated amino group or cytosine molecule remains unclear because the formation of a covalent bond seems to be unlikely. Furthermore, the approaching base must be negatively charged, but the pKa values of cysteine-81and tyrosine-245 are too high (about 10). Therefore, the dissociation of $\mathrm{S}-\mathrm{H}$ and $\mathrm{O}-\mathrm{H}$ bonds of cysteine and tyrosine (Figures 1A and 1B) is very doubtful.

However, the alternative nucleophilic mechanism of epigenetic modifications might be devised. There are numerous examples, which demonstrate superoxide participation in various biological processes under physiologic conditions and especially in pathologic states including cancer and aging. A main difference between physiologic and pathologic states is that pathologies are mostly characterized by superoxide overproduction. Unfortunately, it is not always easy to distinguish the role of superoxide in epigenetic disturbances from the whole ROS effects.

\section{Free Radical and Redox Mechanisms of DNA and Histone Demethylation}

Previously it has been believed that the demethylation reactions of DNA and histones are impossible due to the strong covalent bonds between the methyl substituents and substrate molecules. However, in 2009 Tahiliani et al. showed that 5-methylcytosine can be oxidized to 5hydroxymethylcytosine in the reaction catalyzed by enzyme TET1 [13]. Later on, it has been proposed that these catalytic processes are responsible for the demethylation and deacetylation of the DNA and histone molecules. These processes are carried out by free radical or redox mechanisms, which are fully different from the nucleophilic reactions of methylation and acetylation. DNA demethylation is catalyzed by the ten-eleven translocations (TET) family of dioxygenases through the sequential oxidation of methyl group into hydroxymethyl and carboxyl groups. This reaction takes place in the presence of $\mathrm{Fe}$ (II) ions, 2-oxoglutarate (2OG) and dioxygen. Such a mechanism has been already proposed for iron dioxygenase-catalyzed reactions, for example for non-heme $\mathrm{Fe}(\mathrm{II})$ - and $\alpha$-ketoglutaratedependent dioxygenase TauD [14]. The $\mathrm{Fe}(\mathrm{IV})=\mathrm{O}$ structure of one of intermediates was confirmed by Raman spectra. The two Fe(III) and Fe(II) complexes were also identified. Schematically this mechanism is presented in Figure 2.

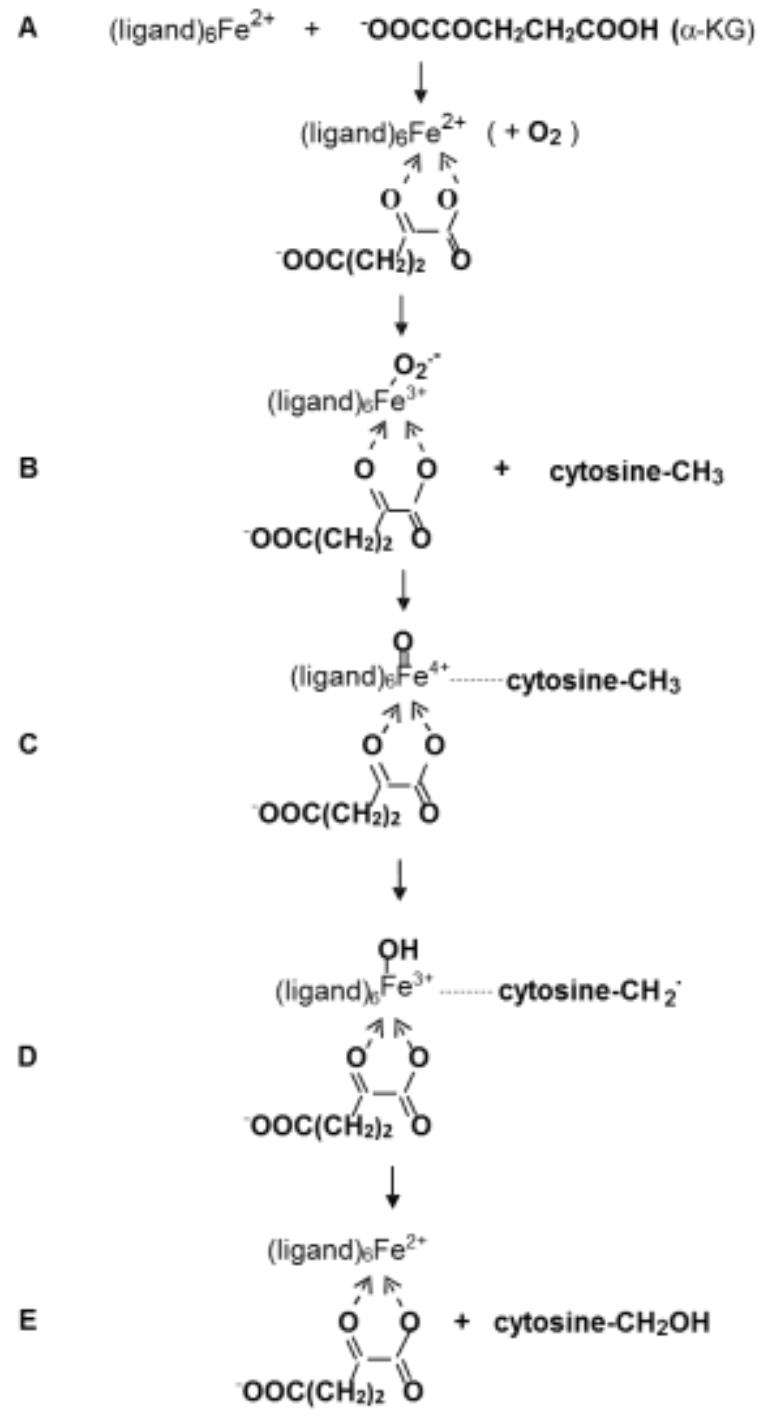

Figure 2. Free Radical Mechanism of DNA demethylation. A. Ensymatic complex. B. Superoxide-bound complex. C. The addition of methylcytosine. D. The formation of free radical. $\mathbf{E}$. The formation of hydroxymethylcytosine. 
A very important stage of the hydroxylation of methyl group in these reactions is the activation of the enzymatic ferrous complex by 2-oxyglutarate with subsequent oxidation of ferrous complex to ferric superoxide. This stage is followed by the formation of the reactive $\mathrm{Fe}(\mathrm{IV})=\mathrm{O}$ species capable of reacting with the methyl group. Recently, similar mechanism has been also proposed for hydroxylation by cytochrome 450 [15].

It is seen from Figure 2 that hydroxylation proceeds through the free radical abstraction of a hydrogen atom from the methyl group. It is possible if the intermediate complex $\mathrm{Fe}(\mathrm{IV})=\mathrm{O}$ is a sufficiently active species able to abstract the hydrogen atom (suggesting that $\mathrm{Fe}(\mathrm{IV})=\mathrm{O}$ can be regarded as the iron derivative of hydroxyl radical):

$$
\mathrm{Fe}(\mathrm{IV})=\mathrm{O}+\mathrm{CH}_{3} \mathrm{R} \rightarrow \mathrm{Fe}(\mathrm{III}) \mathrm{OH}+{ }^{\circ} \mathrm{CH}_{2} \mathrm{R}
$$

The last stage of this process might be considered as the disproportionation of two free radicals:

$\mathrm{Fe}(\mathrm{III}) \mathrm{OH} \leftrightarrow\left[\mathrm{Fe}(\mathrm{II})\left({ }^{\circ} \mathrm{OH}\right)\right]+{ }^{\circ} \mathrm{CH}_{2} \mathrm{R} \rightarrow \mathrm{Fe}(\mathrm{II})+\mathrm{HOCH}_{2} \mathrm{R}$

\section{Enhanced superoxide formation in pathologic states}

It has been shown that superoxide signaling is an important characteristic of epigenetic processes under physiologic conditions, but it is of a more importance for many pathologic disorders which as a rule are characterized by ROS overproduction. From this point of view, cancer and aging are principal examples of pathologies, which are strongly depend on superoxide overproduction. Below we will consider ROS overproduction in cancer, aging, and other diseases including cardiovascular diseases and diabetes mellitus.

\section{Cancer}

Cancer cells are characterized by enhanced level of superoxide and other reactive oxygen species (ROS) [16]. This is typical for prostate cells [17-25], pancreatic cancer cells [26-33], melanoma cells [34-35], breast cancer cells [36-39], and other cancer cells [40-50]. It is important that the elevated ROS formation in cancer cells can have both surviving and hindering effects. Thus, superoxide produced by NADPH oxidase in prostate cancer cells increased cellular immortality through the resistance to programmed cell death [17]. Kumar et $a l$. also found that the enhanced superoxide levels produced by NADPH oxidase in prostate cancer cells associated with the malignant phenotype of prostate cancer [18]. It has been proposed that the expression of NADPH oxidase (Nox1) stimulated superoxide production and signal transduction in cellular proliferation of prostate cancer cells [25]. It was concluded that the Nox 1 protein overexpression was an early event in the development of prostate cancer and that tumors had significantly higher Nox 1 levels than benign prostate tissue. Therefore, Nox 1 overexpression might be as a reversible signal for the proliferation of cancer cells.

Vaquero et al. suggested that pancreatic cancer was so aggressive and unresponsive to the treatment due to its resistance to apoptosis [26]. They concluded that ROS were a pro- survival, anti-apoptotic factor for pancreatic cancer. Superoxide generated by NADPH oxidase (Nox4), probably, transfers a cell survival signal through the protein kinase B - apoptosis signalregulating kinase 1(ASK1) pathway in pancreatic cancer cells and suppresses the enzymatic pathway to apoptosis [30].

\section{Aging and Senescence}

A lot of experimental studies demonstrate ROS overproduction in organismal aging and cellular senescence. It was found that superoxide production was enhanced during lifetime of the rat [51,52]. Gene expression of renal xanthine oxidoreductase increased in aging [53]. Superoxide overproduction was demonstrated in the aged mouse aortic smooth muscle cells [54]. Chen et al. showed the age-related increase in mitochondrial superoxide production in the testosteroneproducing cells of Brown Norway rat testes [55]. Superoxide production by xanthine oxidase and NO synthase in mesenteric arteries from aged rats was higher than in young ones [56].

Endothelial oxidative stress increased in aged healthy men, as well as the expression of NADPH oxidase and NF- $\mathrm{BB}$ [57]. Lener et al. proposed that NADPH oxidase (Nox4) could be responsible for superoxide overproduction in cellular senescence. They showed a significant increase in replicative lifespan of human umbilical vein endothelial cells upon knockdown of Nox4 [58]. ROS enhanced levels might be responsible for the age-dependent endothelial dysfunction in human vessels [59].

Sasaki et al. demonstrated that the rate of superoxide production increased with age in mice, Wistar rats, and pigeons being inversely related to the maximum lifespan of animals [60]. The oxidative stress apparently increases in wealthy humans older than 60 years [61]. Superoxide overproduction from mitochondria in mice led to premature aging [62]. Endothelial vasomotor function decreased in aged mice due to a decrease in extracellular superoxide dismutase (ecSOD) 
[63].

\section{Cardiovascular diseases}

There are well identified sources (NADPH oxidases, xanthine oxidase, and mitochondria) of superoxide production in heart and cardiovascular system which are responsible for many diseases such as heart failure (congestive heart failure or $\mathrm{CHF}$ ), left ventricular hypertrophy (LVH), coronary heart disease, cardiac arrhythmias, etc. Most probably, that superoxide overproduction might be a main reason of the transformation of normal physiological signaling processes into the damaging ones. Mechanisms of ROS overproduction have already been considered [64].

\section{Diabetes mellitus}

It has been shown that hyperglycemic conditions of cells are associated with the enhanced superoxide levels mainly generated by mitochondria and NADPH oxidase. It is known that ROS stimulate many enzymatic cascades under normal physiological conditions, but hyperglycemia causes ROS overproduction and the deregulation of superoxide signaling pathways resulting in diabetes development [65].

\section{Can superoxide and hydrogen peroxide influence differently survival and death of cells?}

Aforementioned data demonstrate the importance of superoxide signaling in many pathologic disorders such as cancer and aging [16], cardiovascular diseases [64], and diabetes mellitus [65]. However, two major ROS species superoxide and hydrogen peroxide can affect biological processes in different ways [66].

As both superoxide and hydrogen peroxide can be formed simultaneously, it is not surprising that the functions of diamagnetic hydrogen peroxide might differ from the paramagnetic free radical superoxide. Below, there are some examples confirming the different effects of superoxide and hydrogen peroxide in cells. Superoxide but not hydrogen peroxide stimulated the phosphorylation of protein kinase C [67]. Superoxide increased the activity of mitogen-activated protein kinase (MAPK), while hydrogen peroxide did not influence the cultured rat aortic vascular smooth muscle cell (VSMC) growth and signal transduction [68]. Hydrogen peroxide and superoxide exhibited different effects on VSMC proliferation and apoptosis: superoxide induced proliferation and hydrogen peroxide stimulated apoptosis [69]. It was found that the $\mathrm{T}$ cell receptor (TCR) activated two distinct pathways of ROS signaling. Hydrogen peroxide formation in $\mathrm{T}$ cells preceded superoxide generation, suggesting that hydrogen peroxide was not formed by dismutation of superoxide. Correspondingly, it was confirmed that superoxide and hydrogen peroxide can participate in separate pathways: hydrogen peroxide regulated phosphorylation catalyzed by extracellular signal-regulated kinase (ERK) (proliferative pathway), while superoxide mediated TCR-stimulated activation of the proapoptotic Fas ligand (FasL) promoter and subsequent cell death [70]. Superoxide stimulated apoptosis in human glioma cells while hydrogen peroxide had no effect [71].

It should be noted that the mechanisms of superoxide and hydrogen peroxide signaling are not fully understood. For example, Pervaiz and coworkers suggested that hydrogen peroxide can stimulate druginduced apoptosis through the intracellular acidification of cancer cells [72-75]. Therefore, superoxide/hydrogen peroxide balance can be regulated between survival and apoptosis in cancer cells through intracellular acidification. However, competition between superoxide and hydrogen peroxide in cells might be more complicated. Thus, Madesh and Hajnoczky showed that superoxide induced rapid cytochrome c release in cells, while hydrogen peroxide failed to stimulate apoptosis [76]. Therefore, superoxide and hydrogen peroxide can be mediators of both survival and death of cancer cells.

\section{Superoxide-dependent epigenetic processes under pathologic conditions}

As it has been shown above, superoxide can participate in many important epigenetic processes including DNA methylation/demethylation, histone methylation/ demethylation, and histone acetylation/deacetylation. Therefore, the disruption of superoxide balance might stimulate dangerous changes in these processes. As it has been discussed above, the effects of superoxide on epigenetic processes might be more prominent ones in pathologic states characterized by the enhanced levels of ROS such as cancer, aging, cardiovascular diseases, and diabetes mellitus. For example, insulin under hyperglycemic condition altered multiple histone modifications by enhanced ROS production inducing lysine 4 and lysine 9 methylation and the acetylation of histone H3 [77]. It has been also shown that an increase in ROS formation under hyperglycemic/ hyperinsulinemic conditions led to a decrease in the histone H3 acetylation, H3 Ser-10 phosphorylation, $\mathrm{H} 3 \mathrm{~K} 4$ methylation and to an increase in $\mathrm{H} 3 \mathrm{~K} 9$ methylation in preadipocytes [78]. Cystic fibrosis (CF) airways, which are exposed to high levels of oxidative stress increased histone acetylation and inflammatory 
gene transcription. Bartling and Drumm suggested that oxidative stress might be responsible for the alternation in HAT/HDAC balance [79].

ROS downregulate catalase through the methylation of its promoter during the development of hepatocellular carcinoma [80]. Transcription factor Oct-1 activated catalase by binding to the catalase promoter and the downregulation of its promoter by ROS-dependent $\mathrm{CpG}$ island methylation in hepatocellular carcinoma [81]. Increased superoxide production stimulated global DNA hypermethylation and increased DNMT1 expression inducing melanocyte malignant transformation [82]. Oxidative stress enhanced the urothelial cell carcinogenesis through the modulation of DNA methylation [83]. It was found that the increased oxidative stress, an important factor of neoplasia development, can induce DNA hypomethylation in prostate tissues [84].

ROS induced DNA methylation of E-cadherin promoter by the activation of histone deacetylase 1 and DNA methyltransferase1 in human hepatocellular carcinoma [85]. Superoxide overproduction apparently increased DNA methylation in melanoma cells [86]. Inactivation of tumor suppressor gene p16 probably played an important role in the progression from Barrett's esophagus (BE) to esophageal adenocarcinoma (EA). It was found that hypermethylation of $p 16$ gene promoter was an important mechanism of p16 inactivation. It is possible that acid reflux presented in BE patients may activate NADPH oxidase NOX5-S and increase superoxide production, which in turn increased p16 promoter methylation and downregulated p16 expression contributing to the progression from $\mathrm{BE}$ to EA [87].

Although majority of studies relating epigenetics and human pathologies are focused on cancer, DNA methylation and histone acetylation associated with the change of redox signaling was also observed in cardiovascular diseases, including atherosclerosis, congestive heart failure, and hypertension [8]. Thus, norepinephrine-induced Nox-dependent superoxide production resulted in an increase in PKC promoter methylation at Egr-1 and $\mathrm{Sp}-1$ binding sites, leading to PKC gene repression and increased ischemic vulnerability in the heart $[89,90]$.

Superoxide overproduction decreased the expression of Sod2 gene due to DNA hypermethylation of a single $\mathrm{CpG}$ dinucleotide close to the transcription site in adult rats with apneas [91]. After nickel exposure, the enhanced superoxide formation resulted in histone hypoacetylation in human leukemia cells [92]. Superoxide overproduction significantly increased the level of H4K12 histone acetylation in porcine oocytes during in vitro aging [93]. Ethanol-induced superoxide generation stimulated histone $\mathrm{H} 3$ acetylation in hepatocytes [94]. Glucose deprivation-induced oxidative stress caused histone deacetylation, the depletion of reduced glutathione (GSH), and the inhibition of HDAC activity [95]. ROS (hydrogen peroxide) silenced the tumor suppresser RUNX3 (runt domain transcription factor 3 promoter) through its hypermethylation [96]. Mitochondrial superoxide generation was an important factor of Kras-mediated tumorigenicity [97]. ROS induced hypomethylation of LINE-1 and hypermethylation of the RUNX3 promoter in a bladder cancer cell line [98]. Superoxide silenced the candidate tumor suppressor gene through ROS-induced methylation and may therefore be associated with the progression of colorectal cancer [99].

It is interesting that the effect of oxidative stress on epigenetic processes might depend on its magnitude. For example, it was found that the moderate superoxide formation during the SUMOylation of HIPK2 (serine/threonine kinase) caused a constitutive association of HDAC3 and kept HIPK2 in the nonacetylated state. However, elevated superoxide formation prevented the SUMOylation of HIPK2 and reduced its association with $\mathrm{HDAC} 3$, increasing the acetylation of HIPK2 [100].

It has been demonstrated above that superoxide levels increased with aging. Therefore, it is important to look at the effects of ROS in epigenetic processes in aging and senescence. Zhang et al. have studied the effects of hydrogen peroxide-stimulated premature senescence on genome methylation and DNA methyltransferases (DNMTs) in human embryonic lung fibroblasts [101]. It was found that the genome methylation level decreased gradually during the premature as well as replicative senescence, which was associated with the reduction in the expression of DNMT1 and global hypomethylation as a distinct feature of senescent cells. Cellular senescence induced by hydrogen peroxide was suppressed by an oncogenic $\mathrm{X}$ protein of hepatitis B virus ( $\mathrm{HBx})$ in human hepatoma cells [102]. It is possible that a decrease in DNA methylation is typical for aging development. For example, Gentilini et al. observed the age-related decrease in global DNA methylation from peripheral leukocytes of 21 female centenarians [103].

However, it should be noted that superoxide might show the opposite effects on aging and longevity. Thus, it has been shown that mitochondrial superoxide might exhibit beneficial effects on extended lifespan [104]. These authors suggested that such "hermetic" mtROS signal could enhance yeast chronological lifespan and regulate aging through epigenetic modulation of nuclear gene expression. 
A.
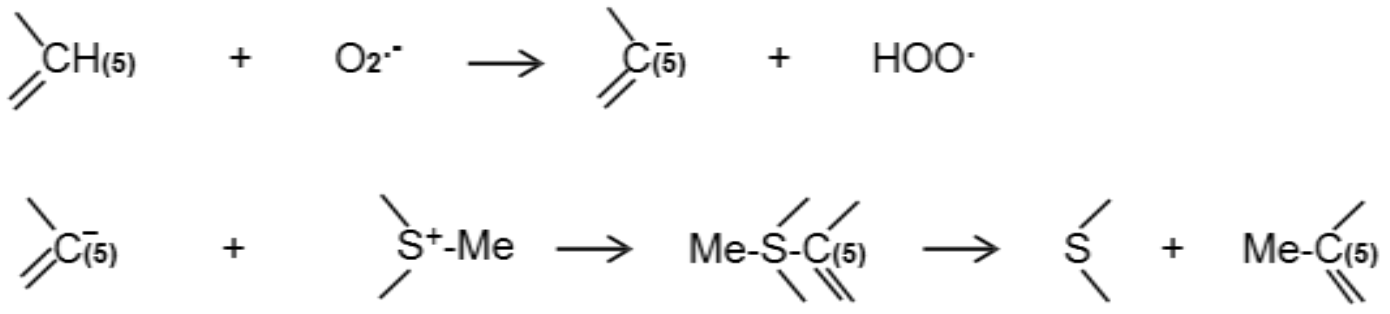

B.

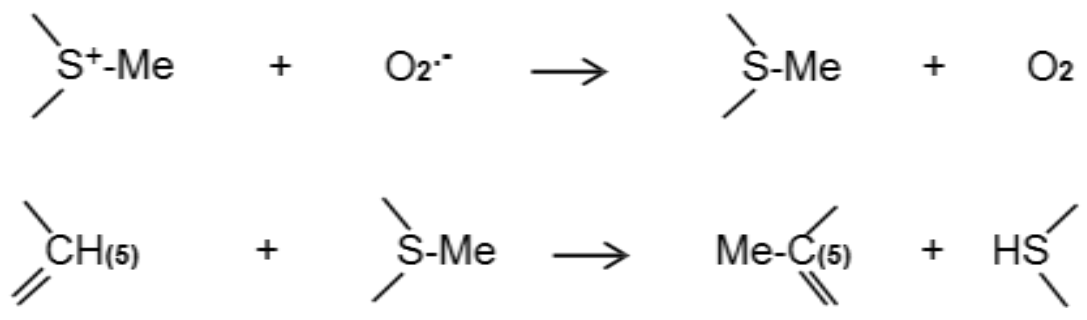

Figure 3. Hypothetic mechanism of superoxide-dependent DNA methylation. A. Mechanism of superoxide participation in DNA methylation through the deprotonation of cytosine. B. Mechanism of superoxide participation in DNA methylation through the neutralization of the positive charge of S-adenosyl-L-methionine (SAM).

\section{Discussion}

It is well known that mitochondria and prooxidant enzymes (xanthine oxidase, NADPH oxidase, or NO oxidase) continuously produce superoxide in cells. Therefore, there are always the superoxide sources capable of participating in nucleophilic processes of DNA and histone methylation and histone acetylation. Superoxide can deprotonate the C-5 position of cytosine and accelerate the addition of methyl group (Figure 3A). On the other hand, superoxide might neutralize a positive charge on the sulfur atom of SAM (Figure 3B). One of these hypothetic reactions can explain the role of superoxide in DNA methylation. Participation of superoxide in DNA methylation and histone modification supports the nucleophilic mechanisms of these processes.

Recent findings demonstrating the direct effects of superoxide on the innermost mechanisms of epigenetic processes are of utmost importance. As it was mentioned, it was earlier believed that DNA methylation is an irreversible reaction. However several authors are now received new experimental proofs of free radical mechanism of DNA demethylation by the stage oxidative mechanism of methyl group of 5methylcytosine (Figure 2). As it can be seen in Figure 2, DNA demethylation is carried out by a free radical mechanism catalyzed by the iron-dependent enzymes ten-eleven translocations (TET) family of dioxygenases. There are several stages, in which free radicals are formed: superoxide at Stage $\mathbf{b}$ and the free radical complex $\left(\mathrm{Fe}^{4+}=\mathrm{O}\right)$ at stage c.

Recently Coulter et al. showed that superoxide generation by hydroquinone exposure caused DNA demethylation in EK293 cells through the activation of Ten Eleven Translocation 15-methylcytosine dioxygenase [105]. Similarly, redox-active quinones, the other superoxide producers activated oxidative conversion of $5 \mathrm{mC}$ to $5 \mathrm{hmC}$ by the TET dioxygenase- catalyzed reaction [106]. Another reducing agent ascorbate accelerates enzymatic reactions, which are catalyzed by $\mathrm{Fe}^{2+}-2$-oxoglutaratedependent family of dioxygenases [107]. However, in contrast to hydroquinone and quinones, which are the well-known producers of superoxide, ascorbate is apparently able to reduce ferric to ferrous ion. It has been found that ascorbate caused widespread specific DNA demethylation [108,109]. Correspondingly, it 
was proposed that ascorbate accelerated the hydroxylation of 5-methylcytosine $(5 \mathrm{mC})$ into 5hydroxymethylcytosine $(5 \mathrm{hmC})$ in DNA demethylation catalyzed by Tet (ten-eleven translocation) methylcytosine dioxygenase [110].

It is now possible to suggest that superoxide participates in epigenetic processes as the two- faced Janus - as a nucleophile in the reactions of nucleophilic substitution (DNA methylation and histone methylation and acetylation) and as a precursor of the reactive free hydroxyl radical in the $\mathrm{Fe}(\mathrm{IV})=\mathrm{O}$ form (DNA and histone demethylation). The role of superoxide in epigenetic nucleophilic processes has already been discussed [11,12], however its transformation into a precursor of reactive free radicals is a new development. For a long time it was established that superoxide can reduce ferric ions into ferrous ions and initiate the ferrous ion-catalyzed reduction of hydrogen peroxide into hydroxyl radicals (the Fenton reaction). In this process superoxide could be the source of reactive free radicals, however all the evidences of such process in biological systems are uncertain. (Recently Cyr and Domann are also considered ROS-dependent mechanisms in epigenetic processes [111]. However, their proposal that hydroxyl radicals might be formed in DNA demethylation by the Fenton reaction seems to be irrelevant). We believe that superoxide is able to influence various epigenetic processes playing the role of a nucleophilic agent in the reactions of methylation and acetylation and of the precursor of reactive radicals in the reactions of demethylation. Future studies of superoxide-dependent epigenetic processes might lead to a better understanding of their mechanisms.

\section{References}

[1] Afanas'ev IB. Superoxide ion: Chemistry and biological implications. Vol. I. CRC Press, Boca Raton, Florida (1989).

[2] Afanas'ev IB. Signaling mechanisms of oxygen and nitrogen free radicals. CRC Press, Taylor \& Francis Group. Boca Raton, Florida (2009).

[3] McCord JM, Fridovich I (1968). The reduction of cytochrome c by milk xanthine oxidase. J Biol Chem, 243: 5753-5760.

[4] Haber F, Weiss J (1934). The catalytic decomposition of hydrogen peroxide by iron salts. Proc R Soc, A147: 332-351.

[5] Fenton HJH (1894). Oxidation of tartaric acid in presence of iron. J Chem Soc Trans, 65: 899-911.

[6] Niehaus WG (1978). A proposed role of superoxide anion as a biological nucleophile in the deesterification of phospholipids. Bioorganic Chemistry, 7: 77-84.

[7] Afanas'ev IB (2005). On mechanism of superoxide signaling under physiological and pathophysiological conditions. Med Hypotheses, 64: 127-129.

[8] Wu LC, Santi DV (1987). Kinetic and catalytic mechanism of HhaI methyltransferase. J Biol Chem, 262: 4778-4786.

[9] Vilkaitis G, Merkiene E, Serva S, Weinhold E, Klimauskas S 2001). The mechanism of DNAcytosine5 methylation. Kinetic and mutational dissection of hhai methyltransferase. J Biol Chem, 276: 20924-20934.

[10] Gerasimaite R, Merkiene E, Klimasauskas S (2011). Direct observation of cytosine flipping and covalent catalysis in a DNA methyltransferase. Nucleic Acids Res, 39: 377-380.

[11] Afanas'ev I (2012). Nucleophilic mechanism of ROS/RNS signaling in cancer epigenetic modifications. Am J Biomed Sci, 4: 285-306.

[12] Afanas'ev I (2013). New nucleophilic mechanisms of ros-dependent epigenetic modification: comparison of aging and cancer. Aging Dis, 5: 52-62.

[13] Tahiliani M, Koh KP, Shen Y, Pastor WA, Bandukwala H, Brudno Y, Agarwal S, Iyer LM, Liu DR, Aravind L, Rao A (2009). Conversion of 5-methylcytosine to 5hydroxymethylcytosine in mammalian DNA by MLL Partner TET1. Science, 324: 930 - 935.

[14] Grzyska PK, Appelmanc EH, Hausingera RP, Proshlyakova DA (2010). Insight into the mechanism of an iron dioxygenase by resolution of steps following the FeIV=O species. Proc Nat Acad Sci USA, 107: 39823987.

[15] Krest CM, Onderko EL, Yosca TH, Calixto JO, Karp RF, Livada J, Rittle J, Green MT (2013). Reactive intermediates in cytochrome P450 catalysis. J Biol Chem, 288, 17074-17081.

[16] Afanas'ev I (2011). Reaction oxygen species signaling in cancer: comparison with aging. Aging Dis, 2:219230.

[17] Brar SS, Corbin Z, Kennedy TP, Hemendinger R, Thornton L, Bommarius B, Arnold RS, Whorton AR, Sturrock AB, Huecksteadt TP, Quinn MT, Krenitsky K, Ardie KG, Lambeth JD, Hoidal JR (2003). NOX5 $\mathrm{NAD}(\mathrm{P}) \mathrm{H}$ oxidase regulates growth and apoptosis in DU 145 prostate cancer cells. Am J Physiol Cell Physiol, 285: C353-C369.

[18] Kumar B, Koul S, Khandrika L, Measchan RB, Koul HK (2008). Oxidative stress is inherent in prostate cancer cells and is required for aggressive phenotype. Cancer Res, 68:1777-1785

[19] Veeramani S, Yuan TC, Lin FF, Lin MF (2008). Mitochondrial redox signaling by p66Shc in involved in regulating androgenic growth stimulation of human prostate cancer cell. Oncogene, 27: 5057-5068.

[20] Singh SV, Choi S, Zeng Y, Haim ER, Xiao D (2007). Guggulsterone-induced apoptosis in human prostate cancer cells is caused by reactive oxygen intermediate dependent activation of c-Jun NH2-terminal kinase. Cancer Res, 67: 7439-7449.

[21] Shukla S, Gupta S (2008). Apigenin-induced prostate cancer cell death is initiated by reactive oxygen species and p53 activation. Free Radic Biol Med, 44: 1833- 
1845.

[22] Antosiewicz J, Herman-Antociewicz A, Marynowski SW, Singh SV (2006). c-Jun NH2-terminal kinase signaling axis regulates diallyl trisulfide-induced generation of reactive oxygen species and cell cycle arrest in human prostate cancer cells. Cancer Res, 66: 5379-5386.

[23] Zhao R, Domann FE, Zhong W (2006). Apoptosis induced by selenomethionine and methioninase is superoxide mediated and p53 dependent in human prostate cancer cells. Mol Cancer Ther, 5: 3275-3284.

[24] Hong HY, Kim BC (2007). Mixed lineage kinase 3 connects reactive oxygen species to c-Jun NH2terminal kinase-induced mitochondrial apoptosis in genipin-treated PC3 human prostate cancer cells. Biochem Biophys Res Commun, 362: 307-312.

[25] Sun Y, St Clair DK, Xu Y, Crook PA, St Clair WH (2010). A NADPH oxidase-dependent redox signaling pathway mediates the selective radio sensitization effect of parthenolide in prostate cancer cells. Cancer Res, 70: 2880-2890.

[26] Vaquero EC, Edderkaoui M, Pandol SJ, Gukovsky I, Gukovskaya AS (2004). Reactive oxygen species produced by $\mathrm{NAD}(\mathrm{P}) \mathrm{H}$ oxidase inhibit apoptosis in pancreatic cancer cells. J Biol Chem, 279: 3464334654.

[27] Cullen JJ, Weydert C, Hinkhouse MM, Ritchie J, Domann FE, Spitz D, Oberley LW(2003). The role of manganese superoxide dismutase in the growth of pancreatic adenocarcinoma. Cancer Res, 63: 12971303.

[28] Weydert C, Roling B, Liu J, Hinkhouse MM, Ritchie JM, Oberley LW, Cullen JJ (2003). Suppression of the malignant phenotype in human pancreatic cancer cells by the overexpression of manganese superoxide dismutase. Mol Cancer Ther, 2: 361-369.

[29] Teoh ML, Sun W, Smith BJ, Oberley LW, Cullen JJ. Modulation of reactive oxygen species in pancreatic cancer. Clin Cancer Res 2007; 13: 7441-7450.

[30] Mochizuki N, Furuta S, Mitsushita J, Shang WH, Ito M, Yokoo Y, Yamaura M, Ishizone S, Nakayagai J, Konagai A, Hirose K, Kiyosawa K, Kamata T (2006). Inhibition of NADPH oxidase activates apoptosis via the AKT/apoptosis signal-regulating kinase 1 pathway in pancreatic cancer PANC-1 cells. Oncogene, 25: 3699-3707.

[31] Lee JK, Edderkaoui M, Truong P, Ohno I, Jang KT, Berti A, Pandol SJ, Gukovsaya AS (2007). NADPH oxidase promotes pancreatic cancer cell survival via inhibiting JAK2 dephosphorylation by tyrosine phosphatases. Gastroenterology, 133: 1637-1648.

[32] Lau ST, Lin ZX, Leung PS (2010). Role of reactive oxygen species in brucein D-mediated p38- mitogenactivated protein kinase and nuclear factor-kappa B signaling pathways in human pancreatic adenocarcinoma cells. Br J Cancer, 102: 583-593.

[33] Brar SS, Kennedy TP, Sturrock AB, Huecksteadt TP, Quinn MT, Whorton AR, Hoidal JR (2002). NAD(P)H oxidase regulates growth and transcription in melanoma cells. Am J Physiol Cell Physiol, 282: 1212-1224.

[34] Govindarajan B, Sligh JE, Vincent BJ, Li M, Canter JA, Nickoloff BJ, Rodenburg RJ, Smeitink JA, Oberley L, Zhang Y, Slingerland J, Arnold RS, Lambeth JD, Cohen C, Hilenski L, Griendling K, Martínez-Diez M, Cuezva JM, Arbiser JL (2007). Overexpression of Akt converts radial growth melanoma to vertical growth melanoma. J Clin Invest, 117: 719-729.

[35] Yamaura M, Mitsushita J, Furuta S, Kiniwa Y, Ashida A, Goto Y, Shang WH, Kubodera M, Kato M, Takata M, Saida T, Kamata T (2009). NADPH oxidase 4 contributes to transformation phenotype of melanoma cells by regulating G2-M cell cycle progression. Cancer Res, 69:2647-2654.

[36] Lin CW, Yang LY, Shen SC, Shen YC (2007). IGF-I plus induces proliferation via activation of ROSdependent ERKs and JNKs in human breast carcinoma cell. J Cell Physiol, 212: 666-674.

[37] Choi JA, Lee JW, Kim H, Kim EY, Seo JM, Ko J, Kim JH (2010). Pro-survival of estrogen receptor-negative breast cancer cells is regulated by a BLT2-reactive oxygen species-linked signaling pathway. Carcinogenesis, 31: 543-551.

[38] Cao XH, Wang AH, Wang CL, Mao DZ, Lu MF, Cui YQ, Jiao RZ (2010). Surfactin induces apoptosis in human breast cancer MCF-7 cells through a ROS/JNKmediated mitochondrial/caspase pathway. Chem Biol Interact, 183: 357-362.

[39] Deng YT, Huang HC, Lin JK (2010). Rotenone induces apoptosis in MCF-7 human breast cancer cell-mediated ROS through JNK and p38 signaling. Mol Carcinog, 49: 141-151.

[40] Shono T, Yokoyama N, Uesaka T, Kuroda J, Takeya R, Yamasaki T, Amano T, Mizoguchi M, Suzuki SO, Niiro H, Miyamoto K, Akashi K, Iwaki T, Sumimoto H, Sasaki T (2008). Enhanced expression of NADPH oxidase Nox4 in human gliomas and its roles in cell proliferation and survival. Int J Cancer, 123: 787-792.

[41] Caja L, Sancho P, Bertran E, Iglesias-Serret D, Gil J, Fabregat I (2009). Overactivation of the MEK/ERK pathway in liver tumor cells confers resistance to TGF\{beta\}-induced cell death through impairing upregulation of the NADPH oxidase NOX4. Cancer Res, 69: 7595-7602.

[42] Chen FH, Zhang LB, Qiang L, Yang Z, Wu T, Zou MJ, Tao L, You QD, Li ZY, Yang Y, Guo QL (2010). Reactive oxygen species-mitochondria pathway involved in LYG-202-induced apoptosis in human hepatocellular carcinoma HepG(2) cells. Cancer Lett, 296: 96-105.

[43] Kim EY, Seo JM, Kim C, Lee JE, Lee KM, Kim $\mathrm{JH}(2010)$. BLT2 promotes the invasion and metastasis of aggressive bladder cancer cells through a reactive oxygen species-linked pathway. Free Radic Biol Med, 49: 1072-1081.

[44] Park IJ, Hwang JT, Kim YM, Ha J, Park OJ (2006). Differential modulation of AMPK signaling pathways by low or high levels of exogenous reactive oxygen species in colon cancer cells. Ann N Y Acad Sci, 1091: 
102-109.

[45] Xia C, Meng Q, Liu LZ, Rojanasakul Y, Wang XR, Jiang BH (2007). Reactive oxygen species regulate angiogenesis and tumor growth through vascular endothelial growth factor. Cancer Res, 67:10823-30.

[46] Chan DW, Liu VW, Tsao GS, Yao KM, Furukawa T, Chan KK, Ngan HY (2008). Loss of MK3 mediated by oxidative stress enhances tumorigenicity and chemiluminescence of ovarian cancer cells. Carcinogenesis, 29: 1742-1750.

[47] Laurent A, Nicco C, Chereau C, Goulvestre C, Alexandre J, Alves A, Levy E, Goldwasser F, Panis Y, Soubrane O, Weill B, Batteux F (2005). Controlling tumor growth by modulating endogenous production of reactive oxygen species. Cancer Res, 65: 948-956.

[48] Schumacker PT (2006). Reactive oxygen species in cancer cells: live by the sword, die by the sword. Cancer Cell, 10: 175-176.

[49] Desouki MM, Kulawiec M, Bansal S, Das GM, Singh KK (2005). Cross talk between mitochondria and superoxide generating NADPH Oxidase in breast and ovarian tumors. Cancer Biol Ther, 4: 1367-1373.

[50] Ma Q, Cavallin LE, Yan B, Zhu S, Duran EM, Wang H, Hale LP, Dong C, Cesarman E, Mesri EA, Goldschmidt-Clermonta PJ (2009). Antitumorigenesis of antioxidants in a transgenic Rac1 model of Kaposi's sarcoma. Proc Natl Acad Sci USA, 106: 8683-8688.

[51] Sawada M, Carlson JC (1987). Changes in superoxide radical and lipid peroxide formation in the brain, heart and liver during the lifetime of the rat (1992). Mech Ageing Dev, 41: 125-137.

[52] Sawada M, Sester U, Carlson JC (1992). Superoxide radical formation and associated biochemical alterations in the plasma membrane of brain, heart, and liver during the lifetime of the rat. J Cell Biochem, 48: 296-304.

[53] Chung HY, Song SH, Kim HJ, Ikeno Y, Yu BP (1999). Modulation of renal xanthine oxidoreductase in aging: gene expression and reactive oxygen species generation. J Nutr Health Aging, 3: 19-23.

[54] Moon SK, Thompson LJ, Madamanchi N, Ballinger Papaconstantinou SJ, Horaist C, Ruuge MS, Patterson C. Aging, oxidative responses, and proliferative capacity in cultured mouse aortic smooth muscle cells. Am J Physiol Heart Circ Physiol 2001; 280: H2779$\mathrm{H} 2788$.

[55] Chen H, Cangello D, Benson S, Folmer J, Zhu H, Trush MA, Zirkin BR (2001). Age related increase in mitochondrial superoxide generation in the testosterone-producing cells of Brown Norway rat testes: relationship to reduced steroidogenic function? Exp Gerontol, 36: 1361-1373.

[56] J acobson AK, Yan C, Gao Q, Rincon-Skinner T, Rivera A, Edwards J, Huang A, Kaley G, Sun D (2007). Aging enhances pressure-induced arterial superoxide formation. Am J Physiol Heart Circ Physiol, 293:13441350.

[57] Donato AJ, Eskurza I, Silver AE, Levy AS, Pierce GL, Gates PE, Seals DR (2007). Direct evidence of endothelial oxidative stress with aging in humans: relation to impaired endothelium-dependent dilation and upregulation of nuclear factor-kappaB. Circ Res, 100:1659-1666.

[58] Lener B, Koziel R, Pircher H, Hutter E, Greussing R, Herndler-Brandstetter D, Hermann M, Unterluggauer H, Jansen-Durr P (2009). The NADPH oxidase Nox4 restricts the replicative lifespan of human endothelial cells. Biochem J, 423: 363-374.

[59] Rodriguez-Manas L, El-Assar M, Vallejo S, LopezDoriga P, Solis J, Petidier R, Montes M, Nevado J, Castro M, Gomez-Guerrero C, Peiro C, SanchezFerrer CF (2009). Endothelial dysfunction in aged humans is related with oxidative stress and vascular inflammation. Aging Cell, 8: 226-238.

[60] Sasaki T, Unno K, Tahara S, Shimada A, Chiba Y, Hoshino M, Kaneko T (2008).Age-related increase of superoxide generation in the brains of mammals and birds. Aging Cell, Apr 14 [Epub ahead of print].

[61] Mendoza-Nunez VM, Ruiz-Ramos M, SanchezRodriguez MA, Retana-Ugalde R, Munoz-Sanchez JL (2007). Aging-related oxidative stress in healthy humans. Tohoku J Exp Med 2007; 213: 20.

[62] Miyazawa M, Ishii T, Yasuda K, Noda S, Onouchi H, Hartman PS, Ishii N (2009). The role of mitochondrial superoxide anion $(\mathrm{O} 2(-))$ on physiological aging in C57BL/6J mice. J Radiat Res, 50: 73-83.

[63] Lund DD, Chu Y, Miller JD, Heistad DD (2009). Protective effect of extracellular superoxide dismutase on endothelial function during aging. Am J Physiol Heart Circ Physiol, 296: H1920-H1925.

[64] Afanas'ev I (2011). ROS and RNS signaling in heart disorders: could antioxidant treatment be successful? Oxid Med Cell Longev 2011; 2011: 293769.

[65] Afanas'ev I (2010). Signaling of reactive oxygen and nitrogen species in Diabetes mellitus. Oxid Med Cell Longev, 3: 361-373.

[66] Afanas'ev IB (2006). Competition between superoxide and hydrogen peroxide signaling in heterolytic enzymatic processes. Med Hypotheses, 66: 1125-1128.

[67] Larsson R, Cerutti P (1989). Translocation and enhancement of phosphotransferase activity of protein kinase c following exposure in mouse epidermal cells to oxidants. Cancer Res, 49: 5627- 5632.

[68] Baas AS, Berk BC (1995). Differential activation of mitogen-activated protein kinases by $\mathrm{H} 2 \mathrm{O} 2$ and $\mathrm{O} 2$.- in vascular smooth muscle cells. Circ Res, 77: 29-36.

[69] Li PF, Dietz R, von Harsdorf (1997). H2O2 and O2.Differential effects of hydrogen peroxide and superoxide anion on apoptosis and proliferation of vascular smooth muscle cells. Circulation, 96: 36023609.

[70] Devadas S, Zaritskaya L, Rhee SG, et al (2002). Discrete generation of superoxide and hydrogen peroxide by $\mathrm{T}$ cell receptor stimulation: selective regulation of mitogen-activated protein kinase activation and fas ligand expression. J Exp Med, 195: 59-70.

[71] Sawada M, Nakashima S, Kiyono T, et al (2001). p53 
regulates ceramide formation by neutral sphingomyelinase through reactive oxygen species in human glioma cells. Oncogene, 20: 1368-1378.

[72] Hirpara JL, Clement M-V, Pervaiz S (2001). Intracellular acidification triggered by mitochondrialderived hydrogen peroxide is an effector mechanism of for drug-induced apoptosis in tumor cells. J Biol Chem, 276: 514-521.

[73] Pervaiz S, Clement MV (2002). A permissive apoptotic environment: function of a decrease in intracellular superoxide anion and cytosolic acidification. Biochem Biophys Res Commun, 290: 1145-1150.

[74] Ahmad KA, Clement M-V, Hamif IM, Pervaiz S (2004). Resveratrol inhibits drug-induced apoptosis in human leukemia cells by creating an intracellular milieu nonpermissive for death execution. Cancer Res, 64: 1452-1459.

[75] Poh TW, Pervaiz S (2005). LY294002 and LY303511 sensitize tumor cells to drug-induced apoptosis via intracellular hydrogen peroxide production independent of the phosphoinositide 3-kinase-Akt pathway. Cancer Res, 65: 6264-6274.

[76] Madesh M, Hajnoczky (2001). VDAC-dependent permeabilization of outer mitochondrial membrane by superoxide induces rapid and massive cytochrome c release. J Cell Biol, 156: 1003-1016.

[77] Kabra DG, Gupta J, Tikoo, K (2009). Insulin induced alteration in post-translational modifications of histone H3 under a hyperglycemic condition in L6 skeletal muscle myoblasts. Biochim Biophys Acta, 1792: 574583.

[78] Gupta J, Tikoo K (2012). Involvement of insulininduced reversible chromatin modeling in altering the expression of oxidative stress-responsive genes under hyperglycemia in 3T3-L1 preadipocytes. Gene, 504,181-191.

[79] Bartling TR, Drumm ML(2009). Oxidative stress causes IL8 promoter hyperacetylation in cystic fibrosis airway cell models. Am J Respir Cell Mol Biol, 40: 58-65.

[80] Min JY, Lim SO, Jung G (2010). Downregulation of catalase by reactive oxygen species via hypermethylation of $\mathrm{CpG}$ island II on the catalase promoter. FEBS Lett, 584: 2427-2432. [81] Quan X, Lim SO, Jung G (2011). Reactive oxygen species downregulate catalase via methylation of a $\mathrm{CpG}$ Island in the Oct-1promoter. FEBS Lett, 585: 3436-3441.

[82] Molognoni F, de Melo FHM, da Silva CT, Jasiulionis MG (2013). Ras and Rac1frequently mutated in melanomas, are activated by superoxide anion, modulate Dnmt1 level and are causally related to melanocyte malignant transformation. PLOS ONE, 8 (Issue 12): e81937.

[83] Sanders YY, Liu H, Zhang X, Hecker L, Bernard K, Desai L, Liu G, Thannickal VJ (2013). Histone modifications in senescence-associated resistance to apoptosis by oxidative stress. Red Biology, 8-16.

[84] Bhusari SS, Dobosy JR, FuV, Almassi N, Oberley T, Jarrard DF (2010). Superoxide dismutase 1 knockdown induces oxidative stress and DNA methylation loss in the prostate. Epigenetics, 5: 402-409.

[85] Lim SO, Gu JM, Kim MS, Kim H, Park YN, Park CK, Cho JW, Park YM, Jung G (2008). Epigenetic changes induced by reactive oxygen species in hepatocellular carcinoma: methylation of the E-cadherin promoter. Gastroenterology, 135: 2128-2140.

[86] Campos AC, Molognoni F, Melo FH, Galdieri LG, Carneiro CR, D’Almeida V, Correa M, Jasiulionis MG (2007). Oxidative stress modulates DNA methylation during melanocyte anchorage blockade associated with malignant transformation. Neoplasia, 9: 1111-1121.

[87] Hong J, Resnick M, Behar J, Wang LJ, Wands J, De Lellis RA, Souza RF, Spechler SJ, Cao W (2010). Acidinduced p16 hypermethylation contributes to development of esophageal adenocarcinoma via activation of NADPH oxidase NOX5-S. Am J Physiol Gastrointest Liver Physiol, 299: G697-706.

[88] Kim GH, Ryan JJ, Archer SL (2013). The role of redox signaling in epigenetic and cardiovascular disease. Antioxid Redox Signal, 18: 1920-1936.

[89] Xiong F, Xiao D, Zhang L (2012). Norepinephrine causes epigenetic repression of PKC gene in rodent hearts by activating Nox1-dependent reactive oxygen species production. FASEB J, 26: 2753 - 2763.

[90] Patterson AJ, Xiao D, Xiong F, Dixon B, Zhang L (2012). Hypoxia-derived oxidative stress mediates epigenetic repression of PKC gene in foetal rat hearts. Cardiovasc Res, 93: 302-310.

[91] Nanduri J, Makarenko V, Reddy VD, Yuan G, Pawar A, Wang N, Khan SA, Zhang X, Kinsman B, Peng YJ, Kumar GK, Fox AP, Godley LA, Semenza GL, Prabhakar N (2012). Epigenetic regulation of hypoxic sensing disrupts cardiorespiratory homeostasis. Proc Natl Acad Sci USA, 109: 2515-2520.

[92] Chen J, Han J, Wang J (2013). Prevention of cytotoxicity of nickel by quercetin: the role of reactive oxygen species and histone acetylation. Toxicol Ind Health, 29: 360-366.

[93] Cui MS, Wang XL, Tang DW, Zang J, Liu Y, Zeng SM (2011). Acetylation of H4K12 in porcine oocytes during in vitro aging: potential role of ooplasmic reactive oxygen species. Theriogenology, 75: 638-646.

[94] Choudhury M, Park PH, Jackson D, Shukla SD (2010). Evidence for the role of oxidative stress in the acetylation of histone $\mathrm{H} 3$ by ethanol in rat hepatocytes. Alcohol, 44: 531- 540.

[95] Druz A, Betenbaugh M, Shiloach J (2012). Glucose depletion activates mmu-miR-466h-5p expression through oxidative stress and inhibition of histone deacetylation. Nucleic Acids Res, 40: 7291-7302.

[96] Kang KA, Zhang R, Kim GY, Bac SC, Hyun JW (2012). Epigenetic changes by oxidative stress in colorectal cancer cells: methylation of tumor suppressor RUNX3. Tumor Biol, 33: 403-412.

[97] Weinberg F, Hamanaka R, Wheaton WW, Weinberg S, Joseph J, Lopez M, Kalyanaraman B, Mutlu GM, Scott Budinger GR, Chandela NS (2010). Mitochondrial metabolism and ROS generation are essential for Krasmediated tumorigenicity. Proc Natl Acad Sci USA, 107: 
8788-8793.

[98] Wongpaiboonwattana W, Tosukhowong P Dissayabutra T, Mutirangura A, Boonla C (2013). Oxidative stress induces hypomethylation of LINE-1 and hypermethylation of the RUNX3 promoter in a bladder cancer cell line. Asian Pac J Cancer Prev, 14: 3773-3778.

[99] Zhang R, Kang KA, Kim KC, Na SY, Chang WY, Kim GY, Kim HS, Hyun JW (2013). Oxidative stress causes epigenetic alteration of CDX1 expression in colorectal cancer cells. Gene, 524: 214-219.

[100] de la Vega L, Grishina I, Moreno R, Kruger M, Braun T, Schmitz MI (2012). A redox-regulated SUMO/acetylation switch of HIPK2 controls the survival threshold to oxidative stress. Mol Cell, 46: 472483.

[101] Zhang W, Ji W, Yang J, Yang L, Chen W, Zhuang Z (2008). Comparison of global DNA methylation profiles in replicative versus premature senescence. Life Sci, 83: 475-480. [102] Kim YJ, Jung JK, Lee SY, Jang KL (2010). Hepatitis B virus X protein overcomes stressinduced premature senescence by repressing p16(INK4a) expression via DNA methylation. Cancer Lett, 288: 226-235.

[103] Gentilini D, Mari D, Castaldi D, Remondini D, Ogliari G, Ostan R, Bucci L, Sirchia SM, Tabano S, Cavagnini F, Monti D, Franceschi C, Di Blasio AM, Vitale G (2013). Role of epigenetics in human aging and longevity: genome-wide DNA methylation profile in centenarians and centenarians' offspring. Age (Dordr), 35: 1961-1973.

[104] Schroeder EA, Raimundo N, Shadel GS (2013). Epigenetic silencing mediates mitochondria stressinduced longevity. Cell Metab, 17: 954-964.
[105] Coulter JB, O'Driscoll CM, Bressler JP (2013). Hydroquinone increases 5-hydroxymethylcytosine formation through Ten Eleven Translocation 1 (TET1) 5-methylcytosine dioxygenase. J Biol Chem, 288, 28792-28800.

[106] Zhao B, Yang Y, Wang X, Chong Z, Yin R, Song S-H, Zhao C, Li C, Huang H, Sun B-F, Wu D, Jin K-X, Song M, Zhu B-Z, Jiang G, Rendtlew Danielsen JM, Xu G-L, Yang Y-G, Wang H (2013). Redox-active quinones induces genome-wide DNA methylation changes by an iron-mediated and Tet-dependent mechanism. Nucleic Acids Res, 10.1093/nar/gkt1090.

[107] Du J, Cullen JJ, Buettner GR (2012). Ascorbic acid: Chemistry, biology and the treatment of cancer. Biochim Biophys Acta, 1826: 443-457.

[108] Cloos PA, Christensen J, Agger K, Helin K (2008). Erasing the methyl mark: histone demethylases at the center of cellular differentiation and disease. Genes Dev, 22: 1115-1140.

[109] Chung TL, Brena RM, Kolle G, Grimmond SM, Berman BP, Laird PW, Pera MF, Wolvetang EJ (2010). Vitamin C promotes widespread yet specific DNA demethylation of the epigenome in human embryonic stem cells. Stem Cells, 28: 1848-1855.

[110] Minor EA, Court BL, Young JI, Wang G (2013). Ascorbate induces Ten-Eleven Translocation (Tet) methylcytosine dioxygenase-mediated generation of 5hydroxymethylcytosine. J Biol Chem, 288: 1366913674.

[111] Cyr AR, Domann FE (2011). The redox basis of epigenetic modifications: from mechanisms to functional consequences. Antioxidants \& Redox Signaling, 15: Number 2. 